\title{
Liberalism, Advanced Liberalism, and the Governmental Policy Challenge in Education
}

Douglas Brown

University of Regina

\begin{abstract}
Governmentality, as credited to Michel Foucault, was developed later on in the theorist's life. In Foucault's understanding of government, or governmentality, our sources of regulation are anchored in the programmes, policies, strategies, methods, thoughts, and actions of our everyday conduct. Governance becomes more a methodology, a practice or rational way of doing things, affecting the way in which power is exercised over ourselves and others. Thus, as governance moves past fixed understandings concerning hierarchical power (state and civil society) subject freedom becomes participant in forms of state organization and regulation. Foucault's approach towards liberalism begs an analysis rationalizing political and educational forms of governance as such an activity. Here liberalism may be viewed as a reflective way of doing things, a method for rationalizing government practices, in that the state will profit and boost control by actually doing less over a citizenry. Under advanced liberalism (neoliberalism) the pathways of state government and self-government collide with even less frequency. Control then is more characteristically the mandate of the individual as citizens become experts of themselves, exerting rituals of personal regulation over bodies, conduct, and minds. This paper scrutinizes the influences of both liberal and advanced liberal administrative streams in Canadian educational policy, asking stakeholders to think long and hard on what is asked of our profession.
\end{abstract}

Keywords: Foucault; governmentality; liberalism; neoliberalism; educational policy 


\section{Liberalism, Advanced Liberalism, and the Governmental Policy Challenge in Education}

\section{Understanding Liberalism: A Workable Analytics for Education}

The term liberalism is often brandished alongside concepts like liberty or personal autonomy. Held up as a doctrine in defiance of excessive state control, liberalism stands as an ethos upholding individual independence, rationality, and reason within a community of like-minded individuals composing a liberal society. Government as a necessary evil is dedicated to upholding these values while minimizing involvement in the world of the citizen. Accompanying such understandings is a language of the political, which problematizes these exchanges, holding state institutions and practices in opposition to things other, or what is labelled civil society. Unfortunately, an idea of a dominating state in need of resistance (of a strict separation of public and private) neglects or ignores the articulation, proliferation, and re-articulation of the everyday. It ignores practices, values, and conducts as played out in the bedrooms, shops, hospitals, and classrooms of a society. Views on liberalism that ignore common forms of societal integration and governance also ignore the mechanism by which citizenship is negotiated in modern democracies. These views ignore how decisions are manufactured and acted upon, and ignore intentional acts of the individual (e.g., efficacy, choice, and selfregulation).

Troubling liberalism as an ideology, or political doctrine, begs a more sophisticated matrix. A more productive analysis links liberalism to a broader social order. For example, can liberalism be viewed as an advancement in the regulation of public conduct? How does liberalism, both as an ethos and practicing politic, work through governable lives--identities in the intellectual, emotional, and technical participation of individuals? Does liberalism foster growth and education, or effectively accommodate competencies and capacities through personal choice.

In a liberal society like Canada, a "good" student is said to be self-made, with that individual adopting a series of proficiencies and practices that become innately individual. Here the actor is held against the state, free to act with minimal impediment from things political (e.g., government or public agencies). However, as a multitude of theorist (educational and otherwise) will argue, in liberal societies education is a political act. There is no shortage of literature here (e.g., phenomenology, critical pedagogy, poststructural theory). As a common thread, the reader is asked to examine linkages between the individual, public, and corporate bodies, and the liberal state. Mechanisms of articulation are then examined in recognizing these linkages and the power dynamics underwriting them. Foucault is such a theorist, providing an analysis of modern liberal states.

Foucault begs a reappraisal of the term political within the context of a modern liberal society (Foucault, 2008). For Foucault, a more informed attention to governance means offering or linkages between political authority and voluntary practice, between the public and the private spheres, and explanations of domination with voluntary activity. The extension of political authority to the aspirations, health, and happiness of the individual implicates a more sophisticated power dynamic. It is necessary to better 
understand how public decisions affecting things like schooling and educational policy are influenced and executed. There is a need to revisit doctrinal understandings of liberalism as guiding mechanisms of social organization and participation in modern liberal states (e.g., Canada).

Importantly, it is beyond the scope of this paper to explain these processes in a given social context (that is this is not a case study in educational policy). It is acknowledged that significant variance occurs from one country to another under various identifiable liberal administrations; from one jurisdiction to another. It is a goal for this paper to examine liberalism, and in turn advanced liberalism, as modern forms of social organization. More importantly, this paper studies societal governance forms as attendant to liberalism/advanced liberalism (reviewing linkages between state function and individual participation). Here Foucault's concept of governmentality is employed (conduct on conduct). In understanding this relationship, at least at a theoretical level, a theorist can better identify governance forms within a given society, informing things like choice and the decision-making process. This is arguably information beneficial to any educator. For example, advanced liberalism varies significantly from the system it is predicated upon (liberalism). Why is this the case? How are these two systems different? How can the migration from one system to another affect educational policy and schooling?

\section{The Liberal State, Education, and Social Participation}

Historically, education under liberal democracy has attained strong rationalizing state support, delivering techniques, incentives, and laws (economic and moral). The motive would indicate a power relationship facilitating right or rational choices for public ends. Specific alterations to the modern liberal state, however, results in alternative forms of organization and change. Consider neoliberalism, or advanced liberalism, a social formation, arguably growing out of modern liberalism yet exhibiting significant adaptations. With advanced liberalism (neoliberalism), an individual's relationship to the state and its agencies changes. That governing processes may prove methodologically dissimilar from one form of social organization to another seems significant but not surprising. As mentioned, liberalism, and in turn advanced liberalism, engages political frameworks that are dissimilar in both product and process. For education, given this variance, we can expect dissimilar ideological and procedural modes of governance invocating disparate political or philosophical practices. However, what the two have in common is the relationship between political conduct and societal practice, a relationship based upon the practicing methods, beliefs, values, and strategies of a participant population.

Unfortunately, political difference is frequently viewed as purely ideological, generating the belief that to change the way schoolchildren are educated only requires that a society change how it understands or views schooling. Pundits promote state leadership in this regard, begging a purely political response. For example, liberal and neoliberal positions can vary on things like school choice, boundary legislation, merit pay, and assessment. The belief is one need only distance one strategy from another to alter the outcome. Selection may demand that we challenge relevant power players within the society (e.g., corporate networks, government parties, legislative boards); however, 
the path is definable and clearly delineated. These assumptions ignore the relationship between governing processes and common practice.

While policy change in education is common, and frequently associated with political change, it is erroneous to accept this correlation as deterministic. For to review educational change is to review the means by which human activity or process becomes bound to that change (as a governmental act) in the formation of personal conduct through subject freedom. The evils of truancy aside, parents choose to send their children to school. This may not always have been the case. Education is a good thing--that is a particular type of education. Here bodies participate in formations of state organization and regulation. Government requires "living human beings" that act, whether as consumers, experts, or criminals (Dean, 2010, p. 22). For example, liberalism may be different from advanced liberalism, but the differences are not by necessity enacted through policies downloaded upon a docile society by an autonomous state. Nor do these differences necessarily reflect top-down institutional modes of delivery (e.g., police, state agencies, school boards).

For Foucault, conduct is forged and delivered through forms of social and cultural participation, namely human habits, practices, beliefs, day-to-day methods of caring for children, recreation, exercise, and evaluation. These conducts may be informed by changes in state leadership, practices of formal agencies, or the structure and operation of quasi-governmental organizations (e.g., Red Cross), but not directly reducible to them. ${ }^{1}$ Governmental conduct in liberal societies is about programmes, policies, strategies acting upon or through life practices, subject formation, and personal regulation. Intuitional variations within a given society (schooling) cannot simply be credited to a series of implemented policies, where state agencies set out to tweak, or eliminate altogether, programs and priorities. Foucault's concept of governmentality is beneficial in furthering the analytics of this process, as here governmental forms not only enforce priorities, institutions, and ideologies; they alter, and are altered by, subjects.

In understanding modern educational change, it is beneficial to view liberalism, or advanced liberalism, as a methodology, a bureaucratic series of practices embedded within a given social. For example, advanced liberalism is frequently associated with aggressive New Right policies and practices. However, advanced liberal (or neoliberalism) forms of administration and governance are more than the enactment of politically motivated hard line and repressive state and institutional measures, measures soliciting the unwitting compliance of powerless victims. Adversaries of neoliberalism may be advantaged in recognising the embedded nature of governmental practices in the everyday world of the citizen. In modern liberal democracies, policy change tends to be achieved with actor complicity, the policy enacted and supported within the liberties and capacities of those governed, not through artifice. With schooling this can mean a general support for policy changes, such as the farming out of educational practices that tout greater user "choice" as the rationale (e.g., the creation of alternative or charter schools, the de-professionalization of teacher organizations) movements that many may, in principle, have criticized in the past: The reason, the new philosophy fits in well with the citizen's present practice or form of governance (how we do things). 
In reconfiguring the relationship of political power to governance, Foucault anchors the political process in the programmes, policies, strategies, methods, thoughts, and actions of everyday conduct (Dean, 2010). Here cultural practice validates the enforcement of political conduct within a given social as individual desires, aspirations, interests and beliefs influence ways of seeing and perceiving, ways of thinking, and characteristic ways of forming subjects, selves, persons, actors, or agents. This is a significant departure from other interpretations promoting hierarchical imbalance, or topdown power flows between state and individual.

With Foucault, governmental formation of conduct accommodates an analytics that evaluates social processes, values, and subjectivities. What makes these practices governmental rather than an assemblage of disparate beliefs or habits is the individual or collective will to make these characteristics technical, to implement them as practice. This is to say that culture matters, as human political conduct is affected through patterned practices. Educational activities, then, within a liberal context are governed through the exercise and application of liberalism as a conduct form. Schooling then may appear somewhat different under liberalism than say, advanced liberalism (neoliberalism).

Arguably, the formulation of educational policy within many Western liberal democracies is as bureaucratic as ideological. Equally so, it involves public participation, as individuals struggle within habits and worldviews reducible to social and cultural participation. Here a more detailed examination of governmentality, as well as liberal and advanced liberal forms of governance will prove useful.

\section{Governmentality--the Conduct of Conduct}

Governmentality can be first credited to Michel Foucault, the concept developed later on in the philosopher's life, purportedly between the late 1970s and his death in 1984. Developed through the Collège de France lectures of the period, governmentality can be interpreted as acting or affecting ways in which individuals become regulated. However, this is not simply about control as interpreted in a negative fashion. Witnessed here is a conduct as exercised through one's autonomy (Donzelot, as cited in Peters et al., 2009). In Foucault's understanding of government, or governmentality, our sources of regulation are anchored in the methods, thoughts, and action of our lived environments. Governmentality regulates populations through biopower or the application and impact of political power on all aspects of human life. For Dean (2010), government implies any means employed to shape our behaviours:

Government is any more or less calculated and rational activity, undertaken by a multiplicity of authorities and agencies, employing a variety of techniques and forms of knowledge, that seeks to shape conduct by working through our desires, aspirations, interests and beliefs, for definite but shifting ends and with a diverse set of relatively unpredictable consequences, effects and outcomes. (p. 18)

The net here can be broadly thrown. For example, ideas of morality and ethics rest upon understandings of self-government and in turn the limits that we place upon ourselves. 
An ensemble of arts and skills entailing the linking of thoughts, affects, forces, artefacts, and techniques that do not simply manufacture and manipulate, but which, more fundamentally, order being, frame it, produce it, make it thinkable, as a certain mode of existence that must be addressed in a particular way. (Rose, as cited in Bennett, 2003, p. 54)

Rather than promoting an interpretation contingent upon oppositional binaries, Foucault employs a power dynamic that is both capillary and limitless in exchanging the either/or for a more dynamic matrix (combining autonomy with responsibility, trust, and consent, and citizenship with accountability). It is as much about how we think about government as government (at least as understood in a more conventional sense). Government is more than implementation through authority in that it begs relationships with the governed through forms of individual and collective identity. The way an individual comes to know government is heterogeneous, involving a multitude of practices, players, and authorities. It is important not to confuse the term with top-down mechanisms of sovereign power (although for Foucault government may incorporate a modern version of the same). The concept of government, as particular forms of knowledge and authority, administrates the processes of "conduct on conduct" (Bennett, 2003, p. 61).

For Dean (2010), government acts on our freedoms, linking technologies of power with rituals of acting. A charter school may seem to be a good idea as one perceives it to offer a greater choice in the education of the young. That an individual may liken this to choices made on a daily basis is not an accident (for example, consumer choices). Under liberal administrations, government is about governing the self, a desire for better health, citizenship, education, and choice. By acting upon our freedom in specific ways, government tempers subject positions. Subject action is not directly correlated to government control. A person may act out, even in situations of extreme coercion, potentially in ways unanticipated by another. Moreover, actions on the part of the subject do not always appear "rational" when appraised by a third party. For example, frequently in-school resistance is far from emancipatory with parents and students supporting policies and positional beliefs, which seemingly, do not advantage them. The collision of social class with school choice serves as an example here as political choice does not necessarily equate to economic choice.

Foucault identifies governance as a complexity or sequence of practices. This understanding is in opposition to more rigid models that stress sovereign hierarchical relationships. For example, some feminist theories may target the embeddedness of patriarchy within government structures. Likewise, Marxists may appeal to the functionalist state, viewed as a site for reproduction of oppressive class relations. While this may be the case, for Foucault, explanations (solely) begging hierarchic relations of power are reductive and incomplete.

As governance moves past fixed understandings concerning hierarchical power (state and civil society), subject freedom becomes participant in forms of organization and regulation. The freedom of the individual then stands in contradiction to the frequently proffered position that pinpoints the state as a unified player, a dispenser of 
cohesion and authority (diplomaticly and militarily). Foucault argues that the state possesses none of this fixity or functionality (Foucault, 2007).

A theorist or citizen, then, should be less concerned with overarching theories of power than with "actions upon actions," or the exercising of power within a given social context (Foucault, 1982, p.220). Simplistic a priori narratives engaging domination and oppression are exchanged for inquiries into the practices of governance. Governance becomes more a methodology, a practice or rational way of doing things. Governmentality references multiple forms of conduct amongst many players. This may include the government of oneself, the government of souls, the government of the household, or the governance of one's children (Foucault, 1991). The formation of governing mechanisms implies connections between the individual and governance forms. Here we have the blending of the "microphysical with the macropolitical" (Burchell, 1996, p. 20), or the linking of the individual practices of the self with forms of external domination. Foucault (as cited in Burchell, 1996) writes:

I think that if one wants to analyse the genealogy of the subject in Western societies, one has to take into account not only techniques of domination, but also techniques of self. Let's say one has to take into account the interaction of these two types of techniques. (p. 20)

The involvement, or exchange, hinging on this analytics of power as government, is set through the interplay of actors and agencies. Governance must be understood as the way in which power is exercised in reciprocal correspondence between self and other, as a means in which our conduct/regulation is bound to institutional and/or state processes.

Dean (2010) stresses the importance in attending to the following assemblages in their entirety:

The routines of bureaucracy; the technology of notation, recording, compiling, presenting and transporting of information; the theories, program, knowledge and expertise that compose a field to be governed and invest it with purposes and objectives; the ways of seeing and representing embedded in practices of government; and the different agencies with various capacities that the practice of government require, elicit, form, and reform. (p. 37)

The relationship assumes the agency or freedom of the body to choose or act otherwise. Foucault argues that the analytics of power (or government) must examine the notion of freedom as both resource and artificer in constitutive government practice (Dean, 2010). The rationality of modern governance is found in both permitting and requiring subject freedom. Foucault writes, "I believe that the concept of governmentality makes it possible to bring out the freedom of the subject and its relationship with others which constitute the very stuff of ethics” (Besley, 2010, p. 532).

It must be understood that government both "individualizes and totalizes" (Besley, 2010, p. 532). For example, school systems under liberal forms of governance individualize students in meritocratic processes that sequester achievers into competitive environments, brandishing the promise of advancement and reward while adhering to rigid demographically defined cohorts. According to Gore (1993), teachers regulate and 
condition students through the very "progressive" practices we employ in the classroom (p. 57). The educated look to expert school cultures for both guidance and the means to determine mastery. Under advanced liberalism, the process is shifted more to the individual. To return to the example of school choice, stakeholders become bound to the school system by the individual choices they make, seemingly in their best interests. Thus, the subject of focus is circumscribed, defined, and incorporated through that person's individuality.

\section{Conduct and Freedom the Neoliberalism/Liberalism Divide}

\section{Liberalism}

Liberalism is often interpreted as a rule of law incorporating the rights and protection of individual freedoms (versus the state). Foucault's approach towards modern liberalism begs an analysis that rationalizes political government as an activity rather than as an institution. Here the formation of the autonomous subject constitutes the backbone as liberalism can be acknowledged for functionally distancing government from sovereign power. Liberalism forms this breach by problematizing the encroachment of the state (or state reason) on a given citizenry. It bears an admission (on the part of the state) of the limitations of state or state authority.

However, liberalism is not the absence of government. It instead invokes a suspicion related to the function of government (means/ends). With liberalism, the "art of government" becomes realizable through the liberties and capacities of those governed (Foucault, 2008, p. 295). It is in this essential incompatibility that the art of government evolves (p. 295). Governance becomes an art, in recognition of the limitations of state, and in recognition of things non-political existing outside of government. Individuality concurrently evolves out of an actor's subjectification in relation to the governing power of state and non-state agencies. A citizen under a liberal form of governance experiences a loosening (without severing) of affiliations between subjectification and subjection. In liberalism, individuals are fashioned out of formerly indentured bodies.

Foucault manufactures a distinct understanding of liberalism as something that is not just a theory, or ideology, or even a set of common policies engaged by government. Liberalism may more appropriately be viewed as a "rationally reflected way of doing things," a method to execute government practices (Burchell, 1996, p. 20). Here the state will profit and boost control by doing less over a citizenry. In turn, the individual subject reciprocates by going about her/his business in a reasonable fashion, as individual freedom is both a condition and result of good government. ${ }^{2}$ In the promotion of both wealth and well-being, society is both object and end of government. A liberal government's task: to discover what techniques, incentives, and laws (economic and moral) facilitate right choices for public ends. The state defines and implements both citizen needs and responses (e.g., medical, social, and educational). Here the state engages in regulatory and legislative actions that resonate in legal, institutional, and cultural interventions intended to govern the conduct of individuals and groups.

Governed individuals in return employ in practical relations via the governing agencies (e.g., ministries, authorities, institutions) articulating their personal freedoms in specific/appropriate ways, that is technologies of self, which are both performative and 
binding (cleanliness, propriety, self-improving). An individual attains relative autonomy and citizenship within a society by becoming a good responsible citizen.

Political rule empowers, at arm's length, a variety of professionals. Thus integrated processes of reflecting and acting manage, guide, and regulate the actions of self. Personal conduct is one both scrutinized and self-reflexive. Gordon argues that this form of experience can be considered governmental in that individual practice renders these actions technical /practical (Gordon, 1991). The technique of good nutrition, for example, occurs in the desire to "effectively fuel and maintain the body" (Dean, 2010, p. 26). Governance, on the other hand, is to be analysed in terms of the strategies, techniques, and procedures through which programs are developed and implemented in relation to specific demands (through a series of complex assemblages, devices, and regulations). Nutritional leadership will occur at the level of the state or organization that provides nutritional information: experts who appraise and plot courses of action and measure success, and programs to provide incentives while disseminating information.

Nikolas Rose has written extensively on liberalism, governmentality, and biopower and is worth investigating here. In Governing "Advanced" Liberal Democracies, Rose (1996) draws the following four significant features of liberalism as an act of government: a new relation between government and knowledge, a novel specification of the subjects of rule as active in their own governance, an intrinsic relation to the authority of expertise, a continual questioning of the activity of rule (Rose, 1996, p. 44). For Rose (2007), government activities are informed by and inextricably tied to the knowledge of human conduct, conduct developed through the scientific disciplines (e.g., the social sciences). Here knowledge becomes instrumental to the "production, circulation, accumulation, authorization, and realization of truth” (Rose, 1996, p. 44).

The compulsory inspection and immunization of school age children serves as an example, as the state measures, records, and accumulates information relevant to the overall health of a population. To achieve its goals, a government may employ social workers, sociologists, statisticians, health care personnel, and teachers in identifying and acting upon a recognizable priority or regulation. The act of government then demands that the agency responsible is somehow in possession of the know-how to make organization possible and direction strategic. Individual complicity is assumed given the requirement that government practice can influence personal conduct through the regulation of the individual. Immunization becomes as much a voluntary act as administrative. Importantly, the process of accumulating and directing knowledge invokes linkages with all that is matter-of-fact in the "prudent" behaviour of the social (Rose, 1996, p. 45). To follow an example used earlier, parents send their children to school to learn. Here under the auspices of liberalism there is an implicit trust in the state and its agents to do the right thing (e.g., the curriculum taught, forms of discipline employed, the credentials of those employed there, assessment strategies used, and accreditation schedules).

What Rose (1996) is referencing is self-government, or the mechanism in which bodies care for themselves, organize their worlds, and regulate their own activities. Governmental bodies thus subsidize a range of practices, which manage and mould the 
individual in specific ways ( p. 45). Failing this, there are a host of institutions created to facilitate this process (e.g., psychiatric hospitals, prisons, and schools).

In the schools (e.g., school curricula), technologies of governance realize the modern subject, as the exercise of individual freedom invites self-conduct in tune with the larger social body. Under liberalism, structured interventions enforce a politic where economic, familial, and social arrangements within a society are governed. For example, the moralization of children might demand the construction and maintenance of a series of schools staffed by teachers, administrators, and councillors, and regulated through boards and ministries. Each is governed through instruments of knowledge /expertise specific to station and situation. The state, then, can govern at a distance, accrediting those actors and agents that may affectively implement comprehensive agenda. Through this process, techniques are created, refined, and disseminated through community practices--schools, workplaces, courtrooms, public agencies (Rose, 1996, 2007). It is in the deployment of forms of expertise that "various ways of speaking the truth, and making it practical, are connected to particular ways of acting on persons" (Bennett, 2003, p. 54).

Liberalism has been identified as distinct from other forms of governance. Under liberalism, critical scrutiny is issued over the activities of state and governance. That is, liberalism sanctions the continual questioning of governance and its effects. This becomes an increasingly pronounced characteristic under advanced liberalism. Liberalism means a certain mistrust of thought and policy as it impacts upon a public--or the question of authority. Here liberalism confronts itself in mode and fashion leading to mistrust and dissatisfaction with government motive, configuration, and delivery. The individual holds a special relationship to the governing body as the freedom of the individual is both threatened and maintained through actions of governance.

Liberalism, as articulated above, is a rationality of government incorporating specific ways that a public thinks about itself and government. This is often referred to as mentalities of government, indicating the beliefs, opinions, and knowledge in which citizens participate as social members (Rose \& Miller, 1992). Specific social technologies, or techniques, underwrite the governmental process as common actions, behaviours, and beliefs incorporate understandings about the world. These techniques draw upon taken-for-granted assumptions regarding points of governmental focus (various philosophies, vocabularies, and management techniques) intertwined with courses of action and conduct, regimes or organizing principles by which a subject rules the body. Schooling incorporates numerous techniques associated to the practice of learning. Curricula production and dissemination, for example, draw from theories on development, learning, and knowledge in assigning a product to a given group. Similarly, curricula production adheres to specific regimes of conduct as time sensitive materials are drafted, referenced, amended, and finally, implemented.

For Foucault, techniques of modern liberalism, and the mentalities that govern them, are often derived from disciplines like the human sciences (e.g., psychology, economics, medicine, and management). Using Dean's example of self-governance and dieting, individuals act from specific assumptions regarding the nature of self, society, and sometimes what lies beyond (spiritual beliefs). Also considered are ideals denoting 
appropriate body types (e.g., weight and level of fitness, image), the role of the self in body discipline, and processes employable as method or action. ${ }^{3}$ For education, disciplines, service agencies, and professionals along with best practices, contribute to a given program articulation. The body, as subject, engages that program.

Liberal governance regulates populations through what has come to be known as bio-politics. Bio-politics can be understood as the application and impact of political power on all elements of human life. Self-governed individuals, then, exercise individual freedoms and at the same time further the security of the social in a tension sponsoring larger economic and social goals. Individual actions carry with them the potential for accommodation, social consequences that can either positively or negatively affect state lead (or sponsored) goals or initiatives. The welfare state incorporates such a tension as governments, and an accompanying series of agencies and organizations, endeavour to maintain the relative security and prosperity of affected populations. In addressing contradictions and difficulties as they occur, contrived agencies and measures are then set in motion to combat or mitigate against failure. Thus, interventions like unemployment insurance, health care, and public education place limits upon individual conduct with the intention of avoiding the off-putting consequences of choice. Arguably, such measures are well within the purview of the liberal state apparatus acting in the greater interest of its constituency. Here specified mentalities and techniques combine to separate liberal forms of governance from other forms of organization and governance. However, liberal societies can and do reference varying technologies in meeting generalizable objectives. Advanced liberal governance forms, for example, vary significantly from those that are social democratic in nature. Exercising a different social location, neoliberals purport that excessive intervention by government apparatuses within and outside of the market are socially and economically costly. This in turn affects the delivery of services such as education as well as the techniques and mentalities familiar to the same. The swing to the advanced liberal or neoliberal position then, while still a modern liberal form of governance, incorporates a different form of appraisal with new exigencies affecting state and non-state governmental functions. For schools this means a different kind of liberalism embracing different conducts of governance. Importantly, as mentioned above, these adjustments are governmental and not solely political.

\section{Advanced Liberalism or Neoliberalism}

Under advanced liberalism, the ground shifts. With the neoliberal state (advanced liberal) significant responsibility is transferred to the individual actor. ${ }^{4}$ This transfer has been described as rolling back the state. By rolling back the state, the state also (at the same time) extends its influence over the individual (into civil society). Thus, the relative freedom of the individual is harnessed in forms of self-governance or connected technologies, linking autonomy with responsibility, trust with consent, and decision making with self-risk. Through reforms predicated upon privatization, competition, and localized management, the neoliberal assemblage governs at an even greater distance than the mainstream liberal formations that are replaced. For with advanced liberalism, extensive decentralization and deregulation encourages the disbanding of state agencies in favour of quasi-public organizations, such as community organizations, professional groups, and private corporations. Under these configurations, highly localized authorities dictate policy at microlevels. Citizens become experts over themselves in the process, 
exerting rituals of personal regulation on bodies, conduct, and minds. Concomitantly, communities are held accountable to absorbed responsibilities and risks (e.g., funding schools and hospitals through entrepreneurial ventures such as raffles, bottle drives, and lotteries). Such ventures constitute the neoliberal subject position, locating or transferring risk and decision making to the level of the individual (e.g., health care, employment, and education) through an action known as the new prudentialism. Within the advanced liberal perspective, existing relationships are altered, as many governmental responsibilities shift from the state to the body. This generally means a shift away from social democratic principles towards a more libertarian value structure.

With advanced liberal forms of governance come amended forms of human conduct, public participation, and truth. An advanced liberal form of governance reconfigures the subject as an instrument of choice, that is to say it embraces a different regime of conduct. Quality of life is now a result of direct choice/risk as the actor moves from a relation of dependency and obligation to self-fulfilment within a series of micromoral domains such as family, workplace, and the school (Rose, 2007). Appropriate life experiences are selected from well-publicized grammars of living as individual existence under advanced liberal systems shifts away from "excessive" forms of state paternalism/guidance and moves towards decision-making processes that focus upon a series of individualized and calculative choices. School choice serves as an example here, as the authority, and thus, the responsibilities related to service provision, are transferred from the state to the new subject (e.g., parent).

Importantly, subject positions are still governable, with identities and allegiances shaped through common competencies and capacities. For example, modern media (television) might replace agencies of state (e.g., occupational therapists, community workers, psychiatric nurses, and councillors) in influencing and affecting forms of personal regulation and maintenance--ill health, unemployment, old age, and ignorance. Insurance against future possibilities materializes in personal choice. Choice, in turn, is informed by what can be labelled as the grey sciences (enumeration, calculation, monitoring, and evaluation). With advanced forms of liberalism, strategic methods of derivation and audit usurp some of the more positivist knowledges of human conduct (as formerly sanctioned through social, economic, and political authority). Under an altered regime of governance and appraisal, a new prudentialism of personal choice tempers obligations and duties struck through the reign of the specialization and control (disciplines). State/agency participation and surveillance, while still present, shift, now occupying more executive roles of administration (e.g., policing). It is the parent's decision on how best to educate her/his children with the state prescribing the conditions of engagement (agencies, accreditation).

School choice then may replace more restrictive and regimented forms of compliance as increases in student/parent decision making, mobility, and participation are substituted for prescriptive and more highly structured forms of governance. Sizable levels of state and professional involvement and regulation, demonstrating significant degrees of formalized intervention, are subordinated to the evaluative choices and commitments of individuals. Forms of public and private regulation are dismantled (e.g., boundary legislation and prescribed curricula). In the process, the authority of experts is 
(at least partially) undermined (e.g., teacher professional organizations, school board associations, and in-school administration).

To draw on the example of nutrition, under liberal social democratic institutions personal nutrition and body maintenance are contextualized within state lead (or supported) programmes, policies, strategies, methods, thoughts, and actions. There is no shortage of experts to research and provide nutritional information. This is complemented by a host of programs to distinguish success from failure, to determine courses of action, and to provide incentives. However, under advanced liberal regimes decisions concerning one's future health are accorded (at least in part) with the accompanying liabilities of choice. Personal technologies brought to bear on the body are now calculations resulting from prudent decisions (calculative dangers and adverted risks) affecting future subject postures. In doing so, knowledge is drawn from a host of differing sources, many located outside of the state (e.g., media). With neoliberal forms of governance the civilizing task-the avoidance of indigency, ignorance, or malnutrition--falls increasingly upon the individual citizen. Government control and paternalism give way to the risk aversion. Subjects absorb responsibility (freedom) for living choices, or the assurance (insurance against) of survival and happiness. Future consequences are reduced to calculations affecting diet, home security, and education. With individualized governance of conduct, experts are experts of self-care in relation to complicit bodies. The authority, and at times legitimacy, of state and non-state agencies are questioned and challenged. With a shift away from authorization, towards choice, the credentials of the professional now underscore suitability rather than entitlement. Teaching credentials do not signify expertise or entitlement but employability. Educators (like any professional) are, under the audit culture, subject to ongoing monitoring and evaluation by the users of that service. Under some neoliberal interpretations and life practices, merit pay makes sense. Teachers are accredited in accordance with added value not credentials.

Enclosure (expertism) thus is penetrated by a series of new techniques of scrutiny (i.e., enumeration, calculation, monitoring, and evaluation). The grey sciences are effective in measuring anything from classroom instruction to the appropriateness of a medical procedure. Central to this modality of governance is the marketing importance of mediation, as personal consumption, expert organization, and prescription are negotiated through individual choice. The new audit society reflects stylistic forms of governance focusing upon individualized mechanisms of appraisal. Welfare agencies or schools are renovated into agencies answerable to market forces. Furthermore, state downloading of responsibilities and accountability (e.g., budgets, curriculum, programs, and student enrolment) onto service providers such as schools serves to atomize and isolate institutions and authorities. Schools are frequently distanced in site-based configurations and expected to compete freely on the market for clients. Audit effectively displaces professionalism as a new degree of visibility in a world of efficiency, appropriateness, and effectiveness.

Under advanced liberalism, expert intervention is measured through individualized choice, as risk is hedged through vigilant monitoring and evaluation. The self-governing community substitutes for citizenship within the common social. The advanced liberal citizen learns the language of accountability and responsibility. Customer demands replacing state sponsored forms of legitimacy and appraisal. 
Accompany this process, quasi-autonomous non-governmental organizations replace state agencies, as professional autonomy is exchanged for the terrain more familiar to audit and choice. Citizens are now underwriters of their own future as failure is no longer the responsibility of the state (e.g., clinical diagnoses, economistic explanations, or societal dysfunction). Sufferers become authors of their own misfortune; replacing what can be viewed as a learned helplessness associate to dependencies developed under forms of social democracy. Ethical reconstruction offers reprieve through a series of selfinitiated services (e.g., self-help, self-worth, and self-esteem).

State membership and authority share significant restrictions in advanced liberal forms of governance. Arguably, advanced liberalism cannot be credited to any one political association, although one must recognize the adeptness of the Right in executing neoliberal policies. Definably, it is the Right rather than the Left that has managed to articulate governance styles consistent with neoliberal principles. The Right has proven successful in articulating social technologies and regimes of the self (or governing ethics of the individual) consistent with advanced liberal modalities. It is also the Right that has translated policy directly into processes/strategies for regulations of problems and difficulties compelling to the new subject. For the classroom, this also means "critical" educators have lost ground in combating these changes.

However, the phenomenon of advanced liberalism is not simply a question of being for or against the present. Although advanced liberalism as a politic is frequently rebuked and resisted by groups such as educators, health care professionals, or unions, countervailing movements have generally failed. Understanding swings in governance forms means understanding and decoding the bureaucratic processes endemic in such affectations. Moreover, partisan intervention is strategically challenging as advanced liberal societies range from the Left to the Right (from Finland to Australia). In the West, advanced liberal and liberal forms of articulations exist concomitantly. Ideological challenges are difficult to sustain and tend to prove ineffective in enacting policy over the long-term. The resiliency of advanced liberal administrations to political attacks and criticisms attests to this. For it remains necessary to link meaningful political change with socio-cultural accommodation. Any motion for change or resistance must be as acceptable to parents and students as to teachers and/or administrators. Under a governance model, if you are going to change a given politic you must first change the practice and engage that politic.

\section{Liberalism, Advanced Liberalism, Resistance, and Points of Convergence}

Alteration in governance results in alternative formations of conduct (e.g., subject formation, care of the self, and social technologies). Governance within a liberal democracy (liberalism or advanced liberalism) is a "reasoned" activity. Anchored in dayto-day methodologies and practices, liberal governance empowers individuals and agencies to act in relatively predictable ways. Social or institutional function and change occurs in recognition of this process. With advanced liberalism, social mechanisms of government, control, and paternalism give way to a new prudentialism. Subjects affect greater responsibility (freedom) for living choices, or the assurance of survival and happiness (e.g., education, health, and superannuation). Future consequences (e.g., calculable dangers and acceptable risks) are calculations affecting things like diet, home 
security, and education through individualised governance of conduct. Citizens embrace specific truth regimes, as played out upon participant bodies, and subject positions in educated and knowledgeable relation to self-care. Importantly, while the individual is answerable to and artificer of bureaucratic practices, we should not see these practices as structures, in that they do not predetermine a given reality. Change is possible, in fact probable. However, it is incorrect to assume that schooling, as a community project, is simply political. The processes of schooling are mired in the routines of the everyday (e.g., values, beliefs, habits, and policies). What makes these routines governable is that they become practice; they are mechanisms influencing conduct and, in turn, regulation.

In recent years, the phenomenon of neoliberalism (both as an ethos and as a series of practices) has drawn significant criticism in countries like Canada, the United Kingdom, Australia, and the United States. Specific to education, critics have maligned policy-driven changes, identifying them as draconian, as less than subtle attempts to deprofessionalize or proletarianize the field (e.g., de-professionalization of teaching, shrinking budgets, and the centralized control of curricula). Recent adaptations include, open jurisdictional boundaries (in both staffing and recruiting), the call for greater school choice (e.g., charter schools, private schools, and alternative schools), the standardization of curricula and assessment, and merit pay. Within the debate forces have become highly polarized, pitting Left against the Right, politicians against acting professionals, and professional associations against think tanks, taxpayer associations, and media. Unfortunately, the act of political contestation can blur or mask substantive issues and complexities as inherent in the act of policy choice. For strong public censure can result in open debate and admonition with groups partitioned, issues reified, and allegiances blurred.

Foucault's work with governmentality--ways in which our conduct becomes bound to institutional and/or state processes--affords the critical insight required in examining this conflation of freedom and power. The debate over standardized assessment can be used in illustration. Standardized methods of assessment are frequently criticized (by both educational professionals and non-professionals) for, arguably, valid reasons. For example, standardized forms of assessment can be said to implement stateled programs of control and surveillance. This is a common criticism and one frequently levelled at governmental administrations. They are also critiqued, remaining, at best, a summative tool, which adds little to learning. In addition, reported data is referenced normatively, frequently used to reward and punish educators, as well as students, depending on how the same fall on the curve. Notably, both liberal and advanced liberal states use this form of assessment, but sport different rationales.

As outlined above, liberal states can be said to further the integrated process of reflecting and acting that manage, guide, and regulate the actions of self through agencies and experts. Standardized assessment techniques can feed into this process. Advanced liberal states may reference other social technologies (e.g., accountability, competition, and client choice). Far from paternalistic, this state looks to prudentialism (e.g., user satisfaction) for validation. Unfortunately, critics of standardized assessment regimes frequently associate those same practices with hierarchical power configurations (an aggressive state, or corporate influence). This may be true but is neither a necessary nor a sufficient cause. We cannot assume that other stakeholders do not sanction these policies. 
A greater executive role by the state (e.g., No Child Left Behind) may be viewed as a productive way of accommodating learning. Advanced liberal administrations often argue that standardized forms of assessment facilitate choice as educational programs can be quantitatively measured and compared. And parents may agree. Witnessed is a different rationale (appraisal) as forged under advanced liberalism. For neoliberal governance, forms of regulation and normalization frequently ask educational participants to assume responsibility for the education process. Social processes and expectations demand that schools bend programs into given strategies and regulations that adhere to a given ethic, or conduct, as embracing a conduct of choice harbours the responsibilities and consequences inherent in the freedom to act. Therefore, in engaging advanced liberal techniques and mentalities, it is plausible to expect the risk takers (e.g., parents, students, and stakeholders) to make choices concerning consumption and organization, which will maximize their comparative advantage in a given situation. Under a varied governance modality the techniques, incentives, and laws (economic and moral), which facilitate right choices for public ends, are penetrated by a differing series of techniques of scrutiny (i.e., what is in it for me and my own). Standardized assessment methods and the information leading from those methods (teacher and school rankings, student rankings, curriculum comparisons) may prove an enticing source of information to the parent used to making consumer choices (life played out as a series of informed decisions) in determining the future success of the child/client. That educational professionals frequently erect an us-versus-state dichotomy in rejecting the use of these exams is not surprising given the social location of the participants (e.g., exam information is frequently used to evaluate teachers and schools). However, parents, taxpayers, and school board associations can find themselves in remarkably different social locations politically given a requisite examination of bureaucratic conventions and practice.

Parental aggression may stand as another example. Today's teachers frequently identify aggressive and abusive parents in reporting occupational stress. It can be argued it has always been such. However, the educator might also look to neoliberalism and the accompanying conduct regimes in searching for explanations. In a society where parents are taking greater ownership for their offspring's education, and ultimately success, there is strategic merit in vigilance. This is particularly relevant in the de-professionalized world of the school where teachers (under advanced liberal modes of conduct) are now service providers rather than experts.

It is not surprising, when calculating the prudent use of time and resources in the classroom, to discover that parents and teachers may not be on the same side. This has been frequently acknowledged in the past by varying theoretical perspectives. However, theorists commonly underplay the role of capillary (horizontal) power configurations in affecting social processes; that is educational issues are analysed in ways that ignore power as cultivated through discourse and practice. A community of parents, stakeholders acting in their own best interests and the interests of their children, may not willingly or reasonably, surrender up that independence and choice to the group. Under some liberal regimes, the outcome may be different, given the primacy of discourse and the role paternalistic state has in underwriting the security of the individual. However, under 
advance liberal practices it is rational to expect a varied outcome. For all members of a community participate in a given social regime.

Similarly, an objection may be lodged by some arguing that middle class and upper-middle class parents have always been active in selecting schools and programs that will best advantage their children. School choice, then, is hardly something new, an observable product of inequality marking given disparities between those who can afford to choose and those who cannot. Here critical educators promote that the social becomes a conditioning factor in student success and accommodation as school knowledge and procedure dovetails with dominant class interests.

However, there are differences. The new prudentialism, as marked through neoliberal governance forms, cuts across class divisions. As indicated, the process is as much bureaucratic as ideological, or structural. That is, governance forms, or conduct on conduct, engage citizens through common/everyday practice. Under neoliberal governance models, the decision to place an offspring in a private school is an individual choice. This is what conflict-oriented critiques miss. Defensibly, under the new audit culture, working class parents invest in similar processes as their middle class counterparts (i.e., calculating risk, auditing information, and making sound decisions). They identify potential educational choices against limitations and liabilities. This carries over into political life as New Right policies, buoyed by advanced liberal governance styles, look considerably different than "old school" conservative governance predecessors.

Of course, parents occupying some social groups will be more successful than others in acting on the choices made. They simply can bring more resources to bear. However, it is short-sighted to endorse class division as a deterministic factor in ascribing a given social order or governance modality. Liberalism and advanced liberalism are two different forms of social organization under modern capitalism, employing differing organizational technologies. Perhaps workers operating under an advanced liberal mechanic are exploitable, and disillusioned. However, it is an error to underestimate the sophistication of the worlds and actors complicit in this ruse. To do so is to alienate and misread.

Notably, Western states combine liberal and advanced liberal modalities within a given social (e.g., education) space. Equally important, Western states differ in how organizational regimes interplay with specific histories, beliefs, value systems, and so on. For example, an advanced liberal regime will look different from one country to another, from one government to another. In Canada, New Right administrations have been given electoral support in a number of provinces. No two look exactly the same. Some brandish Progressive Conservative badges while others are Liberal. However, the similarities are referenced here. To focus on one administration, or even educational system, as an example to the characteristics reviewed above is to misrepresent the more important theoretical connection between a given liberal politic and the community practices associate to it. It is to misunderstand how the practices of a given community become embedded within its institutions and forms of governance. The fact that one administration will look different than another (in West or East) is an argument Foucault convincingly makes; the theorist must acknowledge variance in forms of social 
organization, above theory, or ideology, or a set of common policies engaged by a government. There is no such thing as a pure form or example of these instruments of governance. Perhaps that is the point, as social regulation and governance is a historical process, highly localized, and coded in individualized acts.

Under advanced liberalism, educators have no reason to anticipate a common response or action amongst stakeholders within an educational setting or jurisdiction. This is not to deny the need or purpose in a common response (rallying around a common politic), only the challenges in doing so. One can organize and petition institutions, policies, and practices one finds unacceptable, however, one cannot be assured that others will be stirred to do the same. A parent may be well motivated (as caretaker to her/his child's future) to question the actions of the teacher, to ask why that child finished behind another on an exam, or to move that child to another school. Educators may need to deconstruct assumptions on teaching and learning and emancipatory action. Common practices consistently supplant or imbricate assumed harmonies of ideology and pretence. The parent entrusted with the past actions of his/her child's future cannot be expected to defer to a governing community that, in the process of change, has either lost that authority, or failed to compete as an educational producer.

Schools must be understood within the processes and rituals that govern them, moving past sensibilities anchored in the strong sovereign state. Subject freedom is participant in biopolitical configurations of state organization and regulation. Governmentality references multiple forms of conduct, practices that conjoin these bodies within the larger social. The influences of social conduct cannot be underestimated. The complexity of the everyday warrants our attention and diligence. For social disparities signify more than the need for intervention and realignment; they signify the noise that surrounds that path. 


\section{References}

Bennett, T. (2003). Culture \& government. In J. Bratich, J. Packer, \& C. McCarthy (Eds) Foucault, cultural studies, and governmentality (pp. 47-63). Albany, NY: SUNY.

Besley, T. (2010). Governmentality of youth: Managing risky subjects. Policy Futures in Education, 8, (5), 528-547.

Burchell, G. (1996). Liberal government and the techniques of the self. In A. Barry, T. Osborne, \& N. Rose (Eds.), Foucault and political reason (pp. 19-36). Chicago: IL: University of Chicago Press.

Dean, M. (2010). Governmentality: Power and rule in modern society. London, UK: Sage.

Foucault, M. (1982). The subject and power. In H. L. Dreyfus \& P. Rabinow (Eds.), Michel Foucault: Beyond structuralism and heurmenuetics. Chicago, IL: University of Chicago Press.

Foucault, M. (1991). Governmentality. In G. Burchell, C. Gordon, \& P. Miller (Eds.), The Foucault effect (pp. 87-104). Hemel Hempstead, UK: Harvester Wheatsheaf.

Foucault, M. (2007). Security, territory, population. London, UK: Palgrave.

Foucault, M. (2008). The birth of biopolitics:Lectures at the Collège de France, 19781979 (M. Senellart, Ed). London, UK: Palgrave Macmillan.

Gordon, C. (1991). Governmental rationality: An introduction. In G. Burchell, C. Gordon, \& P. Miller (Eds.), The Foucault effect: Studies in governmentality. Hemel Hempstead, UK: Harvester Wheatsheaf.

Gore, J. (1993). The struggle for pedagogies. New York, NY: Routledge, Chapman and Hall.

Peters, M. A., Besley, A.C., Olssen, M., Maurer, S., \& Weber, S. (2009). Governmentality studies in education. Rotterdam, NL: Sense.

Rose, N. (1996). Governing “advanced” liberal democracies. In A. Barry, T. Osborne, \& N. Rose (Eds.), Foucault and political reason (pp. 37-64). Chicago, IL: University of Chicago Press.

Rose, N. (2007). The politics of life itself: Biomedicine, power, \& subjectivity in the twenty-first century. Princeton, NJ: Princeton University Press.

Rose, N., \& Miller, P. (1992). Political power beyond the state: Problematics of government. British Journal of Sociology, 43(3), 3-27. 


\section{Endnotes}

1 A quasi-autonomous non-governmental organisation is an entity or agency of the government but acts independently from the government in that it is separate and autonomous from the government. Most quasi-autonomous organizations receive government funding and are intended to serve civil society.

2 Burchell (1996) indicates that any discussion of early liberalism, or liberalism as used here, accepts a given historic dynamic with citizens acting economically in their own interest and involving relationships that are relatively indifferent to specified group memberships.

${ }^{3}$ Note that such forms of self-governance are biopolitical in nature because much of what we do and profess to know about diet and dieting is facilitated through societal disciplines (e.g., health sciences, psychology, and sociology) as organizationally disseminated regimes of knowledge.

${ }^{4}$ It is important here to realize that conditions and characteristics of liberalism can and will change against the circumstances from which the strain becomes established. Thus, neoliberalism and neoliberal movements can be interpreted against the previous forms of government in which the critique/movement arises. 